\title{
PERAN SUFISME DALAM MENGATASI PAHAM ISLAM RADIKAL DI INDONESIA
}

\author{
Muhammad Ulil Abshor \\ Pascasarjana UIN Sunan Kalijaga Yogyakarta \\ ulilabshor90@yahoo.com
}

Diterima 23 Februari 2019 | Direview 18 Juni 2019 |Diterbitkan 25 Juni 2019

\begin{abstract}
Radical Islamic Movement or Islamic Radicalism is a movement that has a mindset of textualist ideology, takfiri and truth claim. Basically, the context in which a religious understanding that is claimed to be the final truth, certainly contains an exclusive and offensive element so that some views, flow, and any schools outside is deemed as deviant, because it is far from authoritative sources originating from the Qur'an and the Sunna. This phenomenon does not reflect the peace of Islam as taught by the Prophet as rabmatan lil 'Alamiin (mercy for all nature). This article explores further the importance of the role of Sufism related to the spiritual teachings in it which are the basic foundation in realizing Islam that is peaceful, tolerant, respectful, respectful among fellow human beings especially among other religious people. Islamic teachings extracted in Sufism contain solutive elements in fulfilling the true spirit of Islamic migration (hijra). The Sufism values contain restraints on an "engine of desire" which is now sweeping through modern society. In these conditions, in the face of challenges for the reduction of the spirit of radicalism, consistency (tawak.kal) is needed, namely the form of tireless cleansing of the soul.
\end{abstract}

Keywords: Sufism, Islamic radicalism, cleansing the soul.

\begin{abstract}
Abstrak
Gerakan Islam Radikal atau Radikalisme Islam merupakan gerakan yang memiliki pola pikir ideologi tekstualis, takfiri dan truth claim. Pada dasarnya, konteks di mana sebuah pemahaman keagamaan yang diklaim sebagai kebenaran final, tentu mengandung unsur eksklusif dan ofensif sehingga paham, aliran, madzhab apapun diluar dirinya dianggap menyimpang, karena jauh dari sumber otoritatif yang berasal dari al-Qur'an dan al-Sunnah. Fenomena tersebut tidak mencerminkan kedamaian Islam sebagaimana yang diajarkan oleb Rasulullah Saw. sebagai rabmatan lil 'Alamiin (rabmat bagi seluruh alam). Artikel ini mengeksplor lebih jaub tentang pentingnya peran nilai-nilai sufisme terkait ajaran-ajaran spiritual di dalamnya yang menjadi pondasi
\end{abstract}




\begin{abstract}
pokok dalam merealisasikan Islam yang damai, toleran, saling menghargai, menghormati antar sesama umat manusia terlebih antar umat agama lain. Ajaran Islam yang terekstrak dalam sufisme mengandung unsur solutif dalam memenubi semangat hijrah keislaman yang sesunggubnya. Nilai-nilai sufisme yang dimaksud mengandung pengekangan terhadap sebuah "mesin hasrat" yang kini melanda masyarakat modern. Di dalam kondisi seperti ini, dalam menghadapi tantangan demi berkurangnya spirit radikalisme, diperlukan konsistensi (tawakkal) yaitu bentuk penyucian jiwa yang tak kenal lelah.
\end{abstract}

Kata kunci: Sufisme, Islam radikal, penyucian jiwa

\title{
Pendahuluan
}

Konflik antar umat Islam yang memiliki paham yang berbeda sering kali menimbulkan banyak kerusakan dan kehancuran yang terjadi di muka bumi ini. Hal ini karena paham dan aliran yang berbeda itulah untuk kontek skrang disebut dengan istilah Islam radikal. Islam Radikal memiliki akar historisitas yang kuat mayoritas umat Islam yang tergabung pada kelompok ini memiliki semangat keagamaan yang kuat. ${ }^{1}$ Fenomena ini sebagaimana contoh terjadinya Bom di 3 Gereje berbeda di kota Surabaya tahun silam dengan pelaku yang terindikasi Dita Oeprianto beserta istri dan anak-anaknya merupakan tindakan kriminal yang paling kejam dan biadab. Ini merupakan kekejaman yang terus menerus melanda masyarakan kita di tengah tengah gusaran arus politik kita. Hal Ini memicu timbulnya pemahaman agama yang selama ini diyakini sebagai benar, kebenaran agama yang diyakini oleh mereka bersumber dari al-Qur'an yang dijadikan sebagai legitimasi Jihad fi Sabilillah untuk mewujudkan aksinya yang menelan banyak korban.

Fenemena tersebut jelas bukan mencerminkan ajaran Islam yang sebenarnya, karena hakikat ajaran Islam adalah rahmatan li al-'alamin. Akan tetapi, faktor politik, ekonomi, budaya, militer, baik regional maupun globallah yang menyebabkan terjadinya konflik berdarah dan merusak nilai-nilai kemanusiaan, keadilan, dan keadaban tersebut. Saling menghargai perbedaan dan sikap toleransi terhadap dimensi-dimensi eksklusivitas dalam ajaran agama pihak lain, serta tidak menimbukan sikap fanatismu buta atau negatif yang mengarah pada tindakan radikal sangta penting dilakukan.

Wacana Islam radikal atau Radikalisme Islam belakangan ini membuat panik semua kalangan dari berbagai pihak yang memiliki keterkaitan khusus

\footnotetext{
${ }^{1}$ Usamah Sayyid al-Azhary, Isam Radikal: Telaah Kritis Radikalisme Dari Ikbwanul Muslimin bingga
} ISIS, terj. M. Hidatullah, (Abu Dhabi: Dar al-Fiqih, 2015), 2-3. 
dengan gerakan gerakan fundamental di dunia Islam atau istilhanya fundamentalisme Islam. Fundamentalisme Islam yang dipahami sebagai gerakan yang menentang westernisasi dan ditampilkan sebagai gerakan alternatif system of life bagi masyarakat muslim. Tindakan ekstrem yang dilakukan oleh kelompok Islam Radikal disebabkan oleh baragam faktor, di samping mamahami nash al-Qur'an dan as-Sunnah secara literalis, ada hal yang paling pokok yaitu kurangnya pemahaman yang mendalam tentang pentingnya nilainilai spritual dalam rangka sebagai wujud mendekatkan diri kepada Allah. Namun demikian belakangan, jika pemahaman dalam mendekatkan diri kepada Allah dengan jalan menghancurkan diri dan memusnahkan sesama umat manusia lain, hal ini nampak dalam konteks pemahaman cenderung memfokuskan pada area permukaan yang terjadi dalam Islam. ${ }^{2}$

Islam yang sesungguhnya memiliki konteks ajaran yang universal dan humanisme yaitu hubungan antara hamba dengan Tuhannya (Hablun Min Allah), hubungan antar sesama umat manusia (Hablun Min al-nas). Dalam Islam ajaran yang mencerminkan hubungan seorang hamba dengan Tuhannya, bersifat eksklusif terutama terdapat pada ajaran yang berbasis teologis (tauhid) dan ubudiyah, yakni berkaitan dengan hablun min Allah.

Konsep nilai ajaran dalam mengaitkan hubungan antar sesama manusia (mu'amalah), eksklusivitas hanya ditemukan secara terbatas pada beberapa hal saja. Islam mendorong umatnya untuk membangun korporasi yang damai dan saling memberi keuntungan. Hal ini sebagai bagian yang tak terpisahkan dari kehidupan sistem sosio-religius yang pluralis, oleh karena itu semua umat Islam diharap lebih cerdas dalam memahami dan mengamalkan ajaran agamanya. Pemahaman terhadap Islam yang bersifat inklusif dan terbuka terutama ajaran yang membahas konteks nilai-nilai spiritual dan sufisme hendaknya digalakkan sedemikan hingga dalam merambah ke berbagai sektor kehidupan sosial, pendidikan, ekonomi dan politik dengan mengedepankan kebijaksaan bertindak, sehingga dapat membuahkan keamanan dan kenyamanan, serta kemakmuran hidup bersama sama.

Tindakan aksi terorisme yang melibatkan kekerasan, seperti penembakan, pengeboman, dan bom bunuh diri yang telah dilakuakan kaum radikalisme muslim adalah dengan menjadikan jihad sebagai alasan pembenaran

\footnotetext{
${ }^{2}$ Musa Kazhim, Belajar Menjadi Sufi, cet. I, (Jakarta: Penerbit Lentera, 2003), 26.
} 
sekaligus sebagai landasan teologis. Aksi yang dilakukan sebagai bentuk jihad karena merujuk pada QS: al-Maidah: $44 .{ }^{3}$

Konsep yang dipahami tentang problem Jihad oleh kaum Islam Radikal jika merujuk pada pemaknaan yang sesungguhnya sering kali tidak sesuai dengan makna Jihad yang terdapat dalam ajaran Islam. Sehingga pemaknaan Jihad fi Sabilillah menyimpang dan tidak sesuai dengan kaidah penafisran alQur'an dan Hadis yang baku, malah menimbulkan kesalahfahaman yang fatal, sehingga disalahgunakan oleh mereka kaum radikalisme Islam untuk melegalkan segala cara bentuk kekerasan dalam melakukan aksinya. Kesalahan pemaknaan Jihad malah membuat kelompok orientalist menilai bahwa agama Islam sebagai segerombolon agama yang pemeluknya terjebak pada kubang fanatik agama dengan menyebarkan agama secara syari'at diperbolehkan menggunakan kekuatan senjata. ${ }^{4}$ Untuk itulah penulis mencoba memberi pengamatan dan konsep yang solutif sebagai wujud sumbangan terhadap perkembangan ilmu pengetahuan yaitu berupa pentingnya menumbuhkan peran sufisme (spiritual) dan mengaktivitasikan akal sehat yang diberikan oleh mereka sebagai pemahaman yang pokok dan mendasar.

\section{Sufisme dalam Bingkai Islam}

\section{Pengertian Sufisme}

Sufisme adalah sebuah paham mistik yang mendedikasikan dirinya untuk senantiasa dekat dan bercengkrama dengan Allah poinnya melebur dalam kesatuan diri dengan Allah. ${ }^{5}$ Wacana sufisme ini tercemin dari sosok perilaku Nabi Muhammad terhadap Allah yang memiliki kesadaran mistis yang tinggi. Kesadaran "mistis" menjadi unsur sifat sebagai bentuk gambaran dalam mencerminkan pengalaman gaib Nabi Muhammad yang menjalin kontak dengan-Nya. Sehingga wahyu Allah (al-Qu'an) yang disampaikan melalui Nabi Muhammad mengandung banyak muatan mistis yang menjadi fokus para sufi dalam menunjang klaim meraka untuk mendekatkan diri kepada-Nya.

\footnotetext{
${ }^{3}$ Usamah Sayyid al-Azhary, Isam Radikal: Telaab Kritis Radikalisme Dari Ikhwanul Muslimin Hingga ISIS, terj. M. Hidatullah judul Asli (Abu Dhabi: Dar al-Fiqih, 2015), 7.

${ }^{4}$ Untuk Tahu lebih lanjut cek di Fahrurozi Dahlan, "Jihad Anatara Fenomena Dakwah dan Kekerasan: Mereformulasi Jihad Sebagai Sarana Dakwah”, dalam Jurnal al-Hikmah, Vol. I, No. I, Desember 2008 M/Zulhijjah 1429 H, 71.

${ }^{5}$ Fariduddin Attar, Tad₹kiratul Auliya' terj. Nadya Andwiani, (Bandung: Mizan, 2018), viii.
} 
Perlu diketahui bahwa konteks pemahaman ajaran agama Islam memang sangat kompleks dan plural, namun jika pemahaman terhadap hakikat Islam sebagaimana para sufi memahami apa yang telah Nabi Muhammad alami menjadi acuan besar sehingga wahyu Tuhan tidak parsial dalam wujud pemahaman materi, akan memberi nuansa yang berbeda sebagai realisasi yang kontekstual. Tercermin dalam QS: al-Baqarah: 186.

“ Dan apabila bamba-Ku bertanya kepadamu tentang Aku, Maka (jawablah), babwasanya aku adalah dekat. aku mengabulkan permobonan orang yang berdoa apabila ia memohon kepada-Ku, Maka hendaklah mereka itu memenubi (segala perintah-Ku) dan hendaklah mereka beriman kepadaKu, agar mereka selalu berada dalam kebenaran.” [QS: al-Baqarah: 186.]

Ali bin Abi Thalib pernah berkata kepada Kumail bin Ziyad yang diulas oleh Musa kazhim yang intinya ada tiga tipe manusia di dunia ini pertama, rabbani yang berilmu. Kedua, orang yang senantiasa belajar dan membuka diri kemudian berusaha agar senantiasa berada di jalan kesalamatan. Ketiga, orang awam bodoh dan picik yang mengikuti semua suara antara yang benar dan yang batil tidak bersuluh dengan cahaya Ilmu pengetahuan dan melindungi diri dengan pegangan tauhi yang kuat dan kokoh. ${ }^{6}$

Dalam diri setiap umat manusia itu ada yang namanya Weltanshaung suatu pandangan sikap, pola pikir. Sederhananya adalah kerangka berfikir yang digunakan untuk melihat dunia dan berbagai kejadian yang menyertainya. Berbagai peristiwa yang selalu dimaknai dalam kerangka ini menimbuilkan corak kekacauan, membingungkan dan tak bermakna terlebih lagi konteks kejadian peristiwa pemahaman Islam yang terkesan radikal, sehingga aksi yang dilakukan tak bermakna dan memberi pengaruh postif bagi dirinya. Dalm konteks ini bisa di istilahkan menderita penyakit psikologis yaitu Skizofrenia adalah gerakan pembebasan hasrat yang tak terbendung atau pembebesan diri dari berbagai kungkungan keluarga, masyrakat dan Negara, bahkan agama yang dianggap menghalangi "kebebasan total" yang dengan melepasakan terebut keinginan, hasrat, instink, transformasi dan mutasi dapat memberika ruang hidup yang bebas. ${ }^{7}$

\footnotetext{
${ }^{6}$ Musa Kazhim, Belajar Menjadi Sufi, cet. I, (Jakarta: Penerbit Lentera, 2003), 27.

${ }^{7}$ Mark Seem, "pendahuluan" dalam Gillis Deleuze \& Felix Guattari, Anti-Oedipus, Capitalisme, Schirophrenia (New York: Viking Press, 1982), xx.
} 
Kontribusi sufisme dalam memberikan sebuah "Pengendalian Hasrat" dalam aksi tindakan radikal yang seringkali terjadi di Indonesia perlu digalakkan. Ada sebuah ungkapan sufi yaitu " Hasrat tidak bisa dilawan dengan hasrat, namun dilawan dengan menggunakan akal sehat". ${ }^{8}$ Akal sehat yang dimaksud bukan berarti "akal sehat" yang seringkali didengungkan oleh Rocky Gerung, sama sekali jauh, akal sehat ini yang mampu mengontrol dalam mewujudkan cara berfikir yang adil, utuh, dan menyeluruh, hal ini tercermin dalam konteks nilai manfaat yang dibutuhkan sebagaimana uraian dari Buya Hamka yang dimaksud akal sehat ada sembilan konsep antara lain.

Pertama, orang yang berakal itu luas cara memandang dunia, tidak sempit setiap peristiwa yang dipahami tidakberhenti pada tataran permukaan, namun lebih memahami kompleksitas yang terjadi dalam sebuah peritiswa dan kejadian bahkan teks teks keagamaan. Kedua, orang yang selalu menggunakan waktunya untuk melakukan hal hal yang berfaidah dan bermanfaat buat dirinya sendiri, tidak sampai menilai dan menghakimi orang lain. Ketiga, mempertimbangan perilaku dan berfikir sebelum bertindak dan memutuskan jika ada unsur baik dijalankan jika ada indikasi keburukan ditingglkan. Keempat, mawas diri tahu kekurangan sendiri, senantiasa mengkoreksi kesalahan yang ada dalam dirinya, setelah tahu kesalahanya maka dibuang dan kemudian diperbaiki untuk bertindak yang lebih postif dalam konteks hiudp bermasyarakat. Kelima, tidak gampang berduka cita atas cita cita yang tidak tercapai, tidak pula gampang cemas, terutama dalam memahami setiap pertiwa hidup untuk menghilangkan kegelisahan dan kecemasan. Keenam, menjaga pertemanan dengan orang yang mendorong untuk melakukan tindakan tak benar dan merugikan orang lain. Keetujuh, tidak memandang remeh suatu kesalahan yang dilakukan. Kedelapan, tidak gampang bersedih hati, senantiasa syukur setiap saat dalam keadaan suka dan duka. Kesembilan, hidupnya untuk tidak kepentingan diri sendiri, namun untuk kemanusiaan bermasyarakat secara luas tidak membedakan ras, suku, agama, budaya dan lain sebagainya semua sama di mata Tuhan.'

\footnotetext{
${ }^{8}$ Konteks ini ada dalam tulisan Yasraf Amir Piliang, Dunia Yang Berlari; Mencari Tuban Tuban Digital (Jakarta: Grasindo, 2004), 206.

${ }^{9}$ Hamka, Falsafah Hidup; Memecah Rahasia Berdasarkan Tuntunan al-Qur'an dan As-Sunnab (Jakarta: Republika, 2015), 40.
} 
2. Relasi Islam Radikal dengan Fundamentalisme

Islam Radikal atau radikalisme adalah paham atau aliran yang menghendaki perubahan sosial dan politik dengan cara menggunakan kekerasan sebagai batu loncatan untuk menjustifikasi keyakinan mereka yang dianggap benar. Oleh sebab itu, radikalisme bisa dipahami sebagai paham politik kenegaraan yang menghendaki adanya perubahan dan revolusi besar-besaran sebagai jalan untuk mencapai taraf kemajuan yang signifikan. ${ }^{10}$ Bisa dimaknai bahwa radikalisme adalah suatu paham sosialpolitik yang dalam usaha mencapai tujuannya menggunakan cara kekerasan sehingga radikalisme yang mengatasnamakan agama merupakan sikap keras yang diperagakan oleh sekelompok penganut suatu agama dengan dalih mengamalkan ajaran agama itu.

Islam radikal sebenarnya sudah ada akarnya sejak zaman sahabat, yaitu ketika muncul kaum Khawarij yang tumbuh sebagai golongan paham radikal, baik pandangan politik maupun teologisnya, setelah memuncaknya konflik antara para pendukung Ali bin Abi Thalib r.a. dan pendukung Mu'awiyah r.a. Baik Ali maupun Mu'awiyah, menurut aliran Khawarij, telah melakukan dosa besar yang konsekwensinya dapat dihukumi kafir atau murtad, sehingga halal darahnya. ${ }^{11}$ Akhirnya sejarah mencatat bahwa Ali bin Abi Thalib ditikam oleh seorang Khawarij yang bernama Abdurrahman bin Muljam sampai wafat.

Pemahaman Islam Radikal terus berkembang dengan pasang surutnya sampai dewasa ini di mana saja, termasuk di Indonesia, dan akan tetap muncul sampai kapan pun, karena memiliki akar historis dan teologis. Untuk mencegah tumbuh kembangnya radikalisme, terlebih dahulu harus dipahami apa akar yang menjadi sebab tumbuhnya radikalisme, yaitu paham atau aliran fundamentalisme.

Dalam koridor ilmu pengetahuan bahwa unsur fundamentalisme merupakan sebuah paham yang memfokuskan dalam memperjuangkan sesuatu secara radikal dan fanatik. Sehingga pelakunya adalah penganut gerakan keagamaan yang bersifat kolot dan reaktif yang tetap ngotot ingin kembali ke ajaran agama yang asli seperti yang tersurat dalam kitab suci. Sedangkan fundamentalisme Islam merupakan fenomena sosial di berbagai

${ }^{10}$ Dirjen Bimas Islam Kementrian Agama RI, Radikalisne dan Tantangan Kebangsaan (Jakarta: Dirjen Bimas Islam RI, 2014), 3.

11 Abd. Kholid, Kuliab Madrabib al-Tafsir (IAIN Sunan Ampel Surabaya: Fakultas Ushuluddin, 2003), 56. 
negara sebagai akibat dari derasnya arus modernisasi dan ketidakpuasan terhadap nilai-nilai sosial yang dianggap telah menyimpang dari ajaran Islam yang sesungguhnya.

Aliran fundamentalisme merupakan gerakan protes politik yang diekspresikan dengan term keagamaan yang sering menggunakan tindakan radikal. Kelompok fundamentalisme ini memiliki pandangan epistemologis bahwa Islam adalah satu-satunya jalan hidup yang harus ditegakkan tanpa harus mempertimbangkan akibatnya terhadap hak-hak kelompok atau agama lain. Pandangan kelompok fundamentalisme tersebut terkesan dapat menciptakan tata sosial untuk merealisasikan kebenaran Tuhan, karena Islam menurut mereka tidak hanya sebagai agama unggulan yang terdiri atas keyakinan dan tata ibadah ansich, tetapi juga sebagai pandangan hidup dan tata budaya yang mampu dan layak menata seluruh umat manusia. ${ }^{12}$

Paham fundamentalis masyarakat kita menyebutnya sebagai "teroris" memiliki kesan mengerikan jika didengar karena banyak tindakan dan aksi yang merugikan masyrakat seperti pengeboman, baku tembak, pembakaaran dan lain sebagainya. Konsep teroris para peneliti menyebutnya dengan kelompok yang identik dengan Ikhwanul Muslimin di Mesir, Hizbut Tahrir di Yordania, Hamas di Palestina, Hizbullah di Libanon, Komando Jihad, Usroh, JI, MMI, dan FPI di Indonesia.

Kekerasan dilakukan sebagai bentuk aksi dalam melakukan tindakan, hal ini ini dilakukan semata mata bukan bertujuan untuk menghancurkan umat Islam, akan tetapi sebagai bentuk dalam menciptakan tatanan kenegaraan dan kebangsaan (Negara Islam). Memang pada dasarnya Islam diyakini sebagai satu satunya jalan yang mampu menyelesaikan problem, jalan keluar umat. Maka akar dasar sosial politik ini dijadikan pembenaran oleh paham fundamentalisme yang sikapnya terkenal keras, radikal, intoleran dan tak kenal kompromi, termasuk sikap mereka terhadap Barat yang unfair dalam menjalin hubungan dengan dunia Islam Islam dan juga sikap Amerika dan sekutunya dalam masalah Palestina, Irak, Revolusi Iran, gerakan Wahabiyah Arab Saudi dan lain sebagainya. ${ }^{13}$

Faktor yang mendorong timbulnya paham fundamentalisme dalam ajaran Islam, adalah:

a. Mengalami kegagalan umat Islam dalam menghadapi arus modernisasi arus yang menyudutkan Islam.

${ }^{12}$ David Sagiv, Islam Otentitas Liberalisme (Yogyakarta: LKiS, 1997), 5.

13 Azyumardi Azra, Jaringan Ulama Timur Tengah (Jakarta: Rajawali Press, 1996), 107. 
b. Rasa kesetiakawanan terhadap nasib yang menimpa saudaranya di Palestina, Kashmir, Afganistan, dan Irak.

c. Dalam konteks khas Indonesia, karena kegagalan negara.

d. Dalam merealisasikan cita-cita kemerdekaan berupa tegaknya keadilan sosial dan terciptanya kesejahteraan yang merata bagi seluruh rakyat.

Faktor eksternal, dari paham fundamentalis yang muncul di dunia Islam disebabkan oleh beberapa faktor, antara lain imperialisme, westernisasi, Kristenisasi, sistem pemerintahan, kesenjangan ekonomi, sekularisme, liberalisme, dan terutama sikap Barat yang tidak adil dalam konflik di Timur Tengah, terutama antara Palestina dan Israel. Adapun ciriciri kaum fundamentalisme antara lain sebagai berikut.

a. Fundamentalisme adalah paham yang cenderung sebagai wujud dalam memperjuangkan sesuatu secara radikal, di mana pelakunya adalah penganut gerakan keagamaan yang bersifat kolot dan reaksioner yang selalu ingin kembali ke ajaran agama yang asli seperti yang tersurat dalam kitab suci.

b. Fundamentalisme Islam merupakan fenomena sosial di barbagai Negara sebagai akibat dari derasnya arus modernisasi dan ketidakpuasan terhadap nilai-nilai sosial yang dianggap telah menyimpang dari ajaran Islam yang benar;

c. Melembagakan kepemimpinan agama yang tunggal, monolitik, dan otoritatif, sehingga seorang pemimpin memiliki hak penuh untuk menentukan hitam putihnya agama;

d. Terjadinya klaim kebenaran yang berakibat timbulnya prejudice terhadap kelompok lain.

Karakteristik tentang paham fundamentalis itu terdiri dari lima hal yaitu Pertama, mereka digerakkan oleh kebencian yang sangat besar kepada Barat. Kedua, mereka bersikeras untuk mengembalikan kejayaan peradaban Islam masa lalu. Ketiga, mereka bertujuan mengaplikasikan syari'at Islam dalam tatanan negara. Keempat, kebanyakan mereka memplokamirkan bahwa Islam itu adalah agama dan negara. Kelima, mereka menjadikan masa lalu sebagai penuntun masa depan secara revolusioner. ${ }^{14}$

Atas dasar pemikiran yang terjadi di atas bahwa munculnya paham radikal dan fundamentalis yaitu: Pertama, lengsernya rezim politik yang

${ }^{14}$ Lihat Adian H. Rajam dalam Arus Budaya (Jakarta: Pustaka al-Kautsar Press, 2001), 166. 
berkuasa, di mana kelompok Islam tertentu tidak diberi kebebasan berpendapat. Kedua, gagalnya ideologi yang nampak sekuler dalam menegakkan keadilan, moral, dan kesejahteraan rakyat, sehingga melahirkan radikalisme agama yang diyakini sebagai satu-satunya alternatif ideologis bagi umat Islam. Ketiga, ketidakmampuan kelompok tersebut dalam menghadapi modernitas dan perubahan sosial. Namun, tidak semua gerakan fundamentalisme mesti radikal dalam arti teroris yang sering melakukan kekerasan fisik, karena menurut Jalaluddin Rakhmat, sebenarnya ada empat model fundamentalisme Islam, yaitu:

a. Fundamentalisme sebagai gerakan tajdid, seperti yang dipelopori oleh Ibnu Taimiyah;

b. Fundamentalisme yang timbul sebagai reaksi terhadap modernisme Islam sebagai antitesa terhadap Wahabiyah dan Salafiyah yang dianggap telah mengalami distorsi historis;

c. Fundamentalisme sebagai gerakan yang menentang westernisasi di dalam Islam;

d. Fundamentalisme sebagai suatu keyakinan bahwa Islam menjadi ideologi alternatif. ${ }^{15}$

Model fundamentalisme yang pertama dan kedua kecenderungannya adalah murni perjuangan pemurnian ajaran Islam dari berbagai tradisi lokal yang menyebabkan terkontaminasinya Islam dengan budaya masyarakat, sehingga wajah Islam tidak seperti yang pernah dicontohkan oleh Nabi Muhammad saw. Oleh karena itu fundamentalisme yang model ketiga dan keempat sering mengambil sikap keras dan anarkis dalam mencapai obsesinya yang dikenal dengan radikalisme. Secara umum, semua bentuk kekerasan adalah negatif, tetapi dalam kondisi darurat, kekerasan justeru diperlukan, karena jalan lain sudah tidak ditemukan. Dalam konteks dakwah Islamiyah, metode terbaik adalah pendekatan persuasif dengan konsep "ukbuwab", akan tetapi jika pihak lain bertindak sewenang-wenang, maka "kekerasan" diperlukan. Di sinilah makna "jihad" fisik yang sebenarnya, bukan sekadar instrumen untuk memenuhi keinginan beberapa individu atau kelompok fundamentalis tertentu dalam mencapai ambisi kekuasaan.

${ }^{15}$ Cek di Muhammad Azhar, Fiqih Peradaban, (Yogyakarta: Ittaga Press, 2001), 122-123. 


\section{Peran Sufisme dan Solusi dalam Membendung Islam Radikal}

1. Peran Sufisme

Sufisme dalam pengertiannya telah dijelaskan di atas, namun alasan sufisme sebagai bentuk dalam membendung arus terjadinya tindakan aksi kekerasan karena berangkat dari dalam. Penulis tidak lantas kemudian memberikan arahan yang pokok terkait pentingnya pemahaman sufisme bagi mereka yang sudah berpaham radikal (keras) dan intoleran, akan tetapi yang harus dilakukan adalah aspek pendidikan yang mencerminkan nilai luhur Islam perlu disampaikan kepada mereka, terutama kepada keluarga, sanak famili yang lain.

Pendidikan yang menjurus pada akhlaqul karimah sangat tergantung pada lembaga pendidikan Islam swasta atau lembaga pemerintah Negeri tidaklah cukup dalam mengurai pemahaman yang lebih jelas dan detail. Karena beberapa faktor di antaranya pertama, adanya sumber daya manusia yang kurang memadai dalam memberikan pengajaran keagamaan yang sesuai dengan al-Qur'an dan as-Sunnah. Kedua, menjadikan profesi pendidikan sebagai lahan menumbuhkan pundi pundi kekayaan, terlebih lagi yang setatusnya sebagai ASN, yang dilatarbelakangi oleh niat yang tidak tulus. Ketiga, kurang perhatiannya masyarakat dan orang tua dalam mengawasi anak-anaknya dalam menjalin pergaulan dengan dunia luar, terlebih dengan pesatnya perkebangan teknologi yang tak terbatas. Keempat, pentingnya mencari pembimbing rohaniawan yang mampu mengarhakan jalan menuju kedamaian hidup.

Sufisme dalam kontekstualisasi menjadi faktor pokok dalam memberi aspek "pencerahan" guna membendung -meminjam istilah Amir Yasraf Piliang"mesin hasrat"- terwujudnya arus pemikiran dan pemhaman Islam secara radikal. Pencerahan dalam konteks ini berupa nilai spiritualitas yang mampu membebaskan manusia dari rasa takut, kekuarangan, kelemahan. ${ }^{16}$ Sehingga terbentuknya semangat untuk mengubah diri kearah yang lebih produktif dan kreatif. Namun peran spiritualitas, yang disuarakan oleh orang-orang suci, pejalan sunyi (suluk), suara suara moral suara lembut dari pujangga (seniman) sangat diperlukan dalam mengaktifkan sebuah akal sehat. Namun suara suara mereka untuk konteks

${ }^{16}$ Yasraf Amir Piliang, Dunia Yang Berlari; Dromologi, Implosi, Fatasmogaria (Yogyakarya: Cantrik Pustaka, 2017), 217. 
saat ini mengalami kehilangan yang tak berbeas dilibas oleh arus mesin globalisasi, hilang diseret keterpesonaan dan kegairahan. ${ }^{17}$

Oleh karena untuk membendung arus radikalisme Islam diperlukan kiat kiat yang memadai sebagaimana uraian Husein Muhammad bahwa Islam dapat menjadi sarana untuk menyampaikan sosialisasi terkait dengan isu isu kerjasana dan kerukunan antar umat beragama. Karena dalam konteks tersebut Islam mempu menjadi pioner atau tulang punggung dalam mewujudkan peradaban manusia sebagai realitas yang tidak bisa diganggu oleh siapapun dan apapun. ${ }^{18}$

Membangun sikap toleransi dalam setiap narasi keagamaan diperlukan suatu pemahaman yang penuh damai, sebagai yang diungkap oleh haidar bagir dalam bukunya pentingnya menekankan memahamkan bahwa Islam sebagai agama Cinta yang artinya kasih Sayang, agama yang penuh dengan rahmat bagi seluruh alam. Agama yang mencerimakan keterbukaan dalam bersosialisasi, bagir menyebut para sufi seperti Rabi'ah Adawiyah, Ibn Faridh, Ibn 'Arabi, yang kaya akan pengalana cinta dan kerinduan yang tinggi kepada Tuhan istilahnya Asyik-Masyuq. ${ }^{19}$

\section{Solusi atas Aksi Tindakan Kekerasan}

Kekerasan yang dilakukan oleh kaum dan kelompok radikalisme Islam pada dasarnya sangat mengancam dan membahayakan Stabilitas Bangsa dan Negara, sehingga perlu ada solusi signifikan atas aksi yang dilakukan oleh mereka yang melakuakn tindakan teror, terutama tindakan dan sikap terhadap kaum nonmuslim, kebanyakan dari mereka berangkat dari pemahaman Islam yang kurang kompleks, pemahaman yang merujuk pada nash cenderung lebih bersifat tekstulis dan skriptural. Tidak merujuk pada kaidah kaidah Islam yang lain sebagai tafsir, balaghah, mantik, Ulum alQur'an, Ulum al-hadis sebagai metodologi dalam menggali hukum yang lebih komperhensif, sehingga semangat Islam yang penuh dengan kedamaian tampil secara kontekstual. Namun ada tiga faktor menurut Noor Huda yang dikutip Hiadar Bagir bahwa yang memicu gejala orang yang terlibat

\footnotetext{
${ }^{17}$ Yasraf Amir Piliang, Dunia Yang Berlari; Mencari Tuban Tuban Digital, 204.

18 Hussein Muhammad, Menjadi Pluralisme Kepada Maba Guru Pencerahan (Bandung: Mizan, 2011), 4.

19 Haidar Bagir, dalam "Islam Agama Cinta: Pengantar Penerbit" dalam John D. Caputo, Agama Cinta, Agama Masa depan, terj. Martin Lukito Sinaga, (Bandung: Mizan, 2013)), xi
} 
dalam kekerasan yaitu indiviudu yang terpinggirkan, adanya kelompok yang mendanai dan arus ideologi yang melegitimasi kebenaranya. ${ }^{20}$

Zaman ini merupakan zaman yang penuh dengan kegalauan, makannya banyak frustasi yang dialami dan diakibatkan oleh faktor sosial ekonomi serta imbas persaiangan kelompok politik dan keagamaan lokal, regional, internasional bisa melahirkan paham radikalisme dan terorisme keagamaan seperti yang terjadi belakang ini. Sehingga hal ini perlu suatu pengetahuan wawasan Islam yang lebih kompleks, para pemikira gamawan, rohaniawan yang moderat menjadi suatu tawaran dalam menafsirkan teks keagamaan yang mampu menjadi tandingan pemahaman kelompok sempit kaum fundamentalisme dan Islam Radikal. Peneliti merasa hal ini sangat penting mengingat pemahaman yang bersifat sufistik kiranya menjadi alternatif yang paling efektif dalam mewujudkan pembinaan keagamaan yang memberikan ketentraman, kedamaian jaminan kesalmatan, dan ini semua yang dicari oleh smeua orang. ${ }^{21}$

Namun yang perlu disadari pula adalah peran seorang ilmuwan, intelektual, ulama, pejabat Negara yang bersih juga sangat berpengaruh dalam menentukan sebuah tindakan kekerasan, agar semakin melemah berupa kebijakan dan pengawasan yang ketat dari semua lini dan area pendidikan yaitu perbaikan kurikulum dan perekrutan seorang guru yang lembaga pendidikan berafiliasi oleh pemerintah. Namun jika lembaga pendidikan yang milik pribadi atau swasta perlu adanya pengawasan dari Negara berupa kebijakan dalam mendirikan sekolah perlu adanya sebuah undang undang pendirian lembaga yang bertujuan hanya untuk mendorong semangat Nasionalis semakin ditekankan. Elektabilitas pemerintah dalam mewujudkan Negara yang makmur dibutuhkan peran masyarakat yang lebih egaliter, terbuka dan sosialis. Namun tidak hanya itu elemen yang mendukung semua lembaga pendidikan yang berbasis pada terciptanya spirit keagamaan yang melahirkan jiwa pemahaman atas cinta tanah Air menjadi penting dilakukan.

${ }^{20}$ Haidar Bagir, Islam Tuban Islam Manusia; Agama dan Spiritualitas di Zaman Kacau (Bandung: Mizan, 2017), 41.

${ }^{21}$ Haidar Bagir, “ Akar Ideologi Radikalisme” Kompas 29 Januari 2015. 


\section{Simpulan}

Berangkat dari pembahasan di atas, dapat penulis rangkum poin pokok kesimpulan sebagai berikut.

Pertama, Ekstremisme dari kelompok fundamentalisme secara internal disebabkan oleh beberapa faktor yang memicu gejala orang yang terlibat dalam kekerasan atau fundamentalis yaitu individu yang termarjinalkan, adanya kelompok yang mendanai/ memfasilitasi dan arus ideologi yang melegitimasi kebenaranya.

Kedua, Kaum Islam Radikal dengan berbagai variannya, di dalam memperjuangkan syari'at Islam, penegakan khilafah Islamiyah, dan berbagai agenda lainnya, semuanya bermuara pada satu titik, yaitu kembali kepada alQur'an dan as-Sunnah. Kitab Allah Qur'an dan hadis Nabi atau Sunnah Nabi adalah satu-satunya sumber ajaran, sumber ilmu, dan sumber hukum, serta satu-satunya solusi untuk memecahkan problematika umat. Dalam rangka mampu memcehakan problematika umat diperlukan kaum penafsir dari kalangan agamawan, rohaniawan, intelektual Islam dalam mewujudkan suatu paradigma Islam yang lebih spiritualis. Karena pemhaman ajaran yang menuju hakikat keislaman mampu mendoronga umat beragama senantiasa mewujud dalam karakter dalam mendekatkan diri kepada Tuhan.

Ketiga, pandangan mengenai sikap terhadap peristiwa dan kejadian di dunia ini perlu adanya keterbukaan yang lebih inklusif guna memperoleh suatu konsep Islam yang penuh dengan damii dan cinta. Universalitas Islam yang lebih kontekstual mengakar dalam wujud kehiudpan sosial kemasyarakatan. Artinya nilai ajaran agama yang diterapkan dalam dunia sehari-hari dan penuh penghayatan mampu memberi wujud kedamaian yang mulia.

Keempat, pemahaman keagamaan dan tafsir terhadap teks agama dengan perspektif historis dan sosiologis yang dianggap telah membawa manusia semakin jauh dari doktrin literal kitab suci. Dalam konteks ini, mereka berprinsip bahwa masyarakatlah yang harus menyesuaikan perkembangannya dengan teks kitab suci, bukan sebaliknya.

Kelima, Aksi kekerasan perlu dibendung oleh suatu peran pendidkan yang memadai terutama konsep pemhaman terhadap wacana sufsime yang menggiring umat senantiasa introspeksi terhadap hubungan diri kepada TuhanNya. 


\section{Daftar Pustaka}

Attar, Fariduddin. Tadzkiratul Auliya' terj. Nadya Andwiani. Bandung: Mizan, 2018.

Azra, Azyumardi. Jaringan Ulama Timur Tengah. Jakarta: Rajawali Press, 1996.

Azhar, Muhammad. Fiqih Peradaban. Yogyakarta: Ittaga Press, 2001.

Bagir, Haidar. dalam "Islam Agama Cinta: Pengantar Penerbit" dalam John D.

Caputo, Agama Cinta, Agama Masa depan, terj. Martin Lukito Sinaga. Bandung: Mizan, 2013.

Bagir, Haidar. Islam Tuhan Islam Manusia; Agama dan Spiritualitas di Zaman Kacau. Bandung: Mizan, 2017.

Bagir, Haidar. "Akar Ideologi Radikalisme” Kompas 29 Januari 2015.

Kazhim, Musa. Belajar Menjadi Sufi, cet. I. Jakarta: Penerbit Lentera, 2003.

Kholid, Abd. Kuliah Madzahib al-Tafsir. IAIN Sunan Ampel Surabaya: Fakultas Ushuluddin, 2003.

Dahlan, Fahrurozi. "Jihad Anatara Fenomena Dakwah dan Kekerasan: Mereformulasi Jihad Sebagai Sarana Dakwah", dalam Jurnal al-Hikmah, Vol. I, No. I, Desember 2008 M/Zulhijjah 1429 H.

Dirjen Bimas Islam Kementerian Agama RI, Radikalisne dan Tantangan Kebangsaan. Jakarta: Dirjen Bimas Islam RI, 2014.

H. Adian. Rajam dalam Arus Budaya. Jakarta: Pustaka al-Kautsar Press, 2001.

Hamka, Falsafah Hidup; Memecah Rahasia Berdasarkan Tuntunan al-Qur'an dan AsSunnah. Jakarta: Republika, 2015.

Muhammad, Hussein. Menjadi Pluralisme Kepada Maha Guru Pencerahan. Bandung: Mizan, 2011.

Piliang, Yasraf Amir. Dunia Yang Berlari; Mencari Tuban Tuban Digital. Jakarta: Grasindo, 2004.

Piliang, Yasraf Amir. Dunia Yang Berlari; Dromologi, Implosi, Fatasmogari. Yogyakarya: Cantrik Pustaka, 2017.

Sagiv, David. Islam Otentitas Liberalisme. Yogyakarta: LKiS, 1997.

Sayyid al-Azhary, Usamah. Islam Radikal: Telaah Kritis Radikalisme Dari Ikhwanul Muslimin hingga ISIS, terj. M. Hidatullah. Abu Dhabi: Dar al-Fiqih, 2015.

Seem, Mark. "Pendahuluan" dalam Gillis Deleuze \& Felix Guattari, AntiOedipus, Capitalisme, Schizophrenia. New York: Viking Press, 1982. 
